ISSN (Print) : :1412-7601

ISSN (Online) : 2654-8712

Volume 5, No.1 Maret 2019

EKONOBIS

http://www.ekonobis.unram.ac.id

\title{
Analisis Kebijakan Pengelolaan Buruh Migran(Studi Kasus di Kabupaten Lombok Timur, Nusa Tenggara Barat)
}

\author{
Jalaludin, Irwan Suriadi \\ Universitas Mataram
}

A R T ICLE IN F O $\quad$ Received : 6Februari 2019; Accepted: 29Februari 2019; Published: Maret 2019

Keywords:

Policy, migrant workers

ABSTRACT :Indonesia is one of the countries with the second largest number of migrant workers in ASEAN after the Philippines. Every year no less than 400,000 people leave Indonesia to become migrant workers. On the other hand, although migrant workers make an important contribution to the development of the local and national economy, attention to the protection of migrant workers is still inadequate. As a result, vulnerability and risk in each cycle of migration is increasingly high due to the weak role of the government. This study tries to reveal while analyzing local government policies in dealing with issues related to migrant workers and identifying the economic impacts of sending migrant workers to the regional economy both on a micro and macro scale. The approach used is a qualitative approach to observation, the Indepth Interview and Desk review as data collection techniques. The results of the study indicate that regional policies related to the handling of migrant workers both before, the placement period and after returning to their home areas are still weak. The low level of regional fiscal capacity is a major obstacle for local governments in allocating budgets to adequately foster and protect migrant workers and empowerment programs after returning to their home regions

Kata Kunci :

migran
Kebijakan,buruh

ABSTRAK: Indonesia merupakan salah satu negara dengan jumlah pekerja migran terbesar kedua di ASEAN setelah Filipina. Setiap tahun tidak kurang dari 400.000 orang meninggalkan Indonesia untuk menjadi buruh migran. Di sisi lain meskipun buruh migran memberikan kontribusi penting terhadap pengembangan ekonomi lokal maupun nasional, perhatian terhadap perlindungan buruh migrant, masih belum memadai. Akibatnya kerentanan dan resiko dalam setiap siklus migrasi semakin tinggi karena lemahnya peran pemerintah. Kajian ini mencoba untuk mengungkap sekaligus menganalisis kebijakan pemerintah daerah dalam menangani persoalan-persoalan yang terkait dengan buruh migrant serta mengidentifikasi dampak ekonomi dari pengiriman buruh migran terhadap perekonomian daerah baik dalam skala mikro maupun makro. Pendekatan yang digunakan adalah pendekatan kualitatif dengan Observasi, Indepth Interview dan Desk review sebagai tehnik pengumpulan data. Hasil penelitian menunjukkan bahwa kebijakan daerah terkait penanganan buruh migrant baik sebelum, masa penempatan maupun setelah kembali ke daerah asal masih lemah. Rendahnya kapasitas fiskal daerah menjadi kendala utama bagi pemerintah daerah dalam mengalokasikan anggaran untuk melakukan pembinaan dan perlindungan buruh migran secara memadai serta program pemberdayaan setelah kembali ke daerah asal

Corresponding Author:

Alamat : Program Studi Ekonomi Pembangunan, Fakultas Ekonomi dan Bisnis, Universitas Mataram, Jln. Majapahit No. 62 Mataram.

e-mail: jalaludin@unram.ac.id 


\section{PENDAHULUAN}

\section{Latar Belakang}

Persoalan kependudukan yang dihadapi Indonesia sangat komplek, selain jumlahnya yang besar, juga peroalan kualitas penduduk yang masih rendah. Dari segi kuantitas, jumlah penduduk Indonesia dari tahun ke tahun terus mengalami peningkatan, bahkan cenderung tak terkendali. Pada tahun 1971 jumlah penduduk Indonesia tercatat 119,2 juta, dan dalam kurun dua decade meningkat 60 persen lebih menjadi 179,4 juta (SP. 1990), dan terahir hasil SP 2010 penduduk Indonesia tercatat berjumlah 237,6 juta jiwa dengan LPP 1,49 persen pertahun. Sementara dari segi kualitas, penduduk Indonesia tergolong masih rendah yang ditandai oleh tingkat pendidikan yang masih rendah, angka kemiskinan yang tinggi, tingkat kematian yang masih cukup tinggi dan secara umum Indeks Pembangunan Manusia (IPM) yang masih rendah.

Pertumbuhan penduduk yang tinggi sebenarnya bisa memberikan dampak positif, berupa peningkatan jumlah tenaga kerja yang menjadi unsur penting dalam meningkatkan produksi dan pengembangan ekonomi. Namun jika lapangan pekerjaan yang tersedia tidak cukup menampung jumlah tenaga kerja yang ada maka hal ini justru akan berdampak pada meningkatnya angka pengangguran. Dalam konteks inilah migrasi penduduk ke luar negeri sebagai buruh migrant menjadi salah satu pilihan yang relevan dan menjanjikan sebagai konvensasi kurang atau tidak tersedianya lapangan pekerjaan di dalam negeri.

Persoalan kependudukan di NTB bisa dikatakan paralel dengan masalah kependudukan secara nasional dimana selain jumlah penduduknya yang relative besar dan persebarannya yang tidak merata, juga struktur penduduknya didomnasi oleh kelompok umur usia muda. Berdasarkan data SP 2010 jumlah penduduk NTB adalah 4.500.212 jiwa atau $1,9 \%$ dari jumlah penduduk Indonesia, terdiri dari 2.183.646 penduduk laki- laki dan 2.316.566 perempuan. Dengan jumlah penduduk sebanyak itu menempatkan NTB terutama pulau Lombok menjadi salah satu provinsi yang memiliki penduduk terpadat di Indonesia setelah pulau jawa dan Bali.

Dari segi distribusi penduduk, NTB tergolong timpang dimana 70,41 persen penduduk tinggal di pulau Lombok sementara sisanya 28,59 persen mendiami pulau Sumbawa, padahal pulau Lombok luasnya hanya sepertiga dari luas pulau Sumbawa. Sementara bila dilihat 
distribusi penduduk perkabupaten, dari 10 kabupaten kota yang ada di NTB kabupaten Lombok Timur merupakan kabupaten dengan jumlah penduduk terbesar di NTB dengan jumlah penduduk mencapai 1.153.773 jiwa atau 24,17 persen dari jumlah penduduk NTB yang berjumlah 4.773 .795 jiwa.

Dengan jumlah penduduk yang begitu besar tersebut, tentu membutuhkan tersedianya lapangan kerja yang besar pula, namun pada saat yang sama kemampuan pemerintah dalam menyediakan lapangan pekerjaan terbatas, menyebabkan tenaga kerja di kabupaten Lombok Timur banyak yang mengadu nasib ke luar negeri sebagai buruh migrant. Berdasarkan data BNP2TKI, periode 1- 31 januari 2016, jumlah TKI atau buruh migrant Lombok Timur mencapai 1.990 orang, merupkan jumlah tertinggi, sekaligus menempatkan kabupaten Lombok Timur sebagai pengirim TKI terbanyak dari seluruh kabupaten di Indonesia, disusul oleh kabupaten Indramayu dengan jumlah TKI sebanyak 1.558 dan kabupaten Lombok Tengah sebagai kabupaten ketiga terbesar sebagai pengirim TKI dengan 923 TKI.

Di sisi lain dalam sejarah pengiriman TKI sejak era Orde Baru hingga era pemerintahan sekarang ini, cenderung menempatkan TKI atau buruh migrant sebagai komoditas ekonomi sekaligus penghasil devisa ketimbang sebagai tenaga kerja yang perlu dibina dan dilindungi. Bahkan secara politis, pada zaman pemerintah Orde Baru, para buruh migrant dilabeli sebagai pahlawan devisa. Namun demikian meskipun buruh migran memberikan kontribusi penting terhadap pengembangan ekonomi (lokal bahkan nasional), perhatian pemerintah terhadap perlindungan buruh migrant, baik di dalam negeri maupun di luar negeri masih sangat lemah. Akibatnya kerentanan dan resiko dalam setiap siklus migrasi semakin tinggi karena lemahnya peran pemerintah tersebut.

Bertolak dari kenyataan tersebut, kajian/ tulisan ini mencoba untuk mengungkap peran pemerintah atau tepatnya politik lokal/ kebijakan pemerintah daerah dalam menangani persoalan- persoalan yang terkait dengan pembinaan dan perlindungan buruh migrant baik sebelum diberangkatkan, selama penempatan dan purna penempatan atau setelah mereka kembali ke daerah asal.

Pendekatan yang digunakan dalam kajian ini adalah pendekatan kualitatif dengan menerapkan beberapa metode pengambilan data yakni : (i). Observasi/Pengamatan, tujuannya adalah untuk mendapatkan gambaran tentang 
kondisi umum wilayah penelitian (social setting, physical setting dII) melalui dokumentasi foto/gambar; (ii). Indepth Interview dengan sejumlah key informan yang dipilih secara purposive berdasarkan kebutuhan penelitian yang dalam hal ini terdiri dari unsur-unsur Anggota Dewan Perwakilan Daerah (DPRD), SKPD bidang Kependudukan kabupaten Lombok Timur, Tokoh Masyarakat, dan LSM yang mempunyai kepeduliant terhadap buruh migran ; (iii). Desk review : kajian ini juga dilengkapi review terhadap data sekunder baik berupa laporan-laporan sebelumnya (laporan penelitian, laporan program) maupun data statistik lainnya untuk mendukung informasi dari lapangan (data primer).

\section{KAJIAN PUSTAKA}

\section{Buruh Migran Dan Sejarah Migrasi Di} Indonesia

Migrasi adalah proses perpindahan dari satu wilayah ke wilayah lain baik dalam satu negara maupun antar negara, sementara migran/imigran adalah penyebutan untuk orang yang melakukan imigrasi. Konvensi ILO tentang buruh migrant tahun 1949 butir 97 article 11 mendefinisikan buruh migrant sebagai orang yang bermigrasi dari suatu negara ke negara lain untuk tujuan bekerja. Sedangkan menurut UU No. 39, tahun
2004 tentang penempatan dan perlindungan Tenaga Kerja di Luar negeri pasal 1 ayat 1 , mendefinisikan buruh migrant atau Tenaga Kerja Indonesia yang selanjutnya disebut dengan TKI adalah setiap warga negara yang memenuhi syaratuntuk bekerja di luar negeri dalam hubungan kerja untuk jangka waktu tertentu dengan menerima upah.

Sejarah migrasi sangat boleh jadi setua peradaban manusia itu sendiri. Hal ini sejalan dengan hakekat manusia sebagai homo homini socio (makhluk sosial) yang selalu membangun interaksi dengan dunia luar untuk mempertahankan eksistensinya. Sama seperti halnya migrasi yang dilakukan oleh burung dari utara menuju selatan, yang mencari tempat hangat dan sumber makanan tiap tahunnya, maka seorang yang bermigrasi sejatinya mempunyai tujuan melakukan proses perpindahan tersebut. Jika kita tarik ke sejarah perkembangan manusia di masa ribuan tahun yang lalu, migrasi sesungguhnya telah terjadi dengan tujuan mencari sumber makanan, dimana satu kelompok manusia purba bahkan mampu bermigrasi antar benua dan saling berperang dengan kelompok lain untuk memperebutkan sumber makanan di daerah tersebut. 
|56Jalaludin, Irwan Suriadi/Analisis KebijakanPengelolaan...

Indonesia sendiri memiliki catatan panjang mengenai sejarah migrasi dan mobilitas penduduk.Dalam beberapa literatur, di sebutkan bahwa migrasi orang-orang Indonesia ke luar negeri mulai dilakukan pada masa pemerintah Hindia Belanda melalui penempatan buruh kontrak ke beberpa negara seperti Suriname dan Afrika Selatan yang juga merupakan wilayah jajahan Belanda. Total penempatan orang Indonesia ke kedua wilayah yang disebutkan mencapai 32.986 orang dengan menggunakan kapal laut dalam beberapa gelombang.

Gelombang pertama pengiriman TKI diberangkatkan dari Batavia dengan menggunakan Kapal "SS Koningin Emma" pada tanggal 21 Mei 1890 menuju Suriname dan tiba pada 9 Agustus 1890 sebanyak 94 orang terdiri dari 61 pria dewasa dan 31 perempuan, termasuk membawa 2 anak-anak yang dipekerjakan pada perkebunan tebu dan pabrik gula "Marienbung," Suriname.

Pengiriman pekerja migran ke Suriname waktu itu didominasi oleh orang Jawa karena rendahnya tingkat perekonomian penduduk Jawa pasca meletusnya Gunung Merapi tahun 1872 dan pertimbangan soal kepadatan penduduk di Pulau Jawa. Tidak mengherankan sampai dengan tahun
2004 penduduk Jawa di Suriname menempatai urutan ke 4 dengan jumlah mencapai 71.879 orang $(14,6$ persen) dari 492.829 jiwa penduduk Suriname. (Balawala Mansetus, 2016)

\section{Kebijakan Migrasi Dari Masa Ke Masa}

Dalam Kamus Besar Bahasa Indonesia kata politik berarti pengetahuan mengenai ketatanegaraan atau kenegaraan, juga bisa berarti segala urusan dan tindakan (kebijakan, siasat, dan sebagainya) mengenai pemerintahan negara atau terhadap negara lain atau juga berarti cara bertindak dalam menghadapi atau menangani suatu masalah. Dengan pengertian ini maka kata politik bisa bersesuaian dengan kata kebijakan.

Aristoteles mendefinisikan politik sebagai upaya atau cara untuk memperoleh sesuatu yang dikehendaki (Hedi, 2013) atau juga bisa berarti segala sesuatu tentang proses perumusan dan pelaksanaan kebijakan publik. Sementara kebijakan public sendiri diartikan sebagai serangkaian langkah atau tindakan (termasuk keputusan untuk tidak bertindak) yang dilakukan oleh pihak yang yang memegang otoritas (dalam hal ini adalah pemerintah) untuk mencapai tujuan public (social) tertentu (Darwin, 2015) 
Jalaludin, Irwan Suriadi/Analisis Kebijakan Pengelolaan... . 57

Dari pengertian politik dan kebijakan di atas, maka yang dimaksud dengan politik local dalam penelitian ini adalah kebijakan- kebijakan yang diambil oleh pemerintah daerah, dalam hal ini pemerintah daerah kabupaten Lombom Timur dalam menangani persoalan yang terkait dengan buruh migrant.

Bila kita merunut kebijakan migrasi dalam rentang sejarah panjang kemerdekaan Indonesia, maka kita akan menemukan dinamika kebijakan yang telah ditempuh oleh pemerintah dalam setiap rezim kekuasaan. Kebijakan yang terkait dengan buruh migrant ternyata memiliki karakteristik yang berbeda dalam setiap rezim pemerintahan.Di masa orde lama tak banyak kebijakan migrasi yang dibuat pemerintah tentang pengerahan tenaga kerja yang melintasi batas negara, karena pemerintah saat itu masih sibuk mengurusi konsolidasi politik dalam negeri.

Kebijakan penanganan buruh migrant dimulai di era Orde Baru yaitu tahun 1970 dengan dikeluarkannya kebijakan Antar Kerja Antar Daerah (AKAD) dan Antar Kerja Antar Negara (AKAN) yang kemudian dituangkan dalam bentuk Peraturan Pemerintah No.4 Tahun 1970. Peraturan ini memberikan wewenang kepada pemerintah dan pihak swasta untuk mengatur proses pengiriman TKI ke luar negeri. Setelah peraturan ini dikeluarkan maka pengurusan tenaga kerja bisa dipegang oleh swasta selain pemerintah hingga saat ini.

Seiring perjalanan waktu, dan semakin meningkatnya jumlah pekerja migran Indonesia, maka pada tahun 1988, Menteri Tenaga Kerja saat itu, Cosmas Batubara (1988-1993), mengeluarkan Peraturan Pemerintah (PerMen) No. 5 yang mengatur tentang pengiriman tenaga kerja ke luar negeri dan Keputusan Menteri Tenaga Kerja No. 1307 tentang Petunjuk teknis pengerahan TKI ke Arab Saudi. Arab Saudi menjadi negara pertama tujuan penempatan buruh migran yang sebagian besar bekerja di sektor domestik.Hal ini menggeser penempatan buruh migran yang sebelumnya bersifat adhoc (pasif) menjadi kebijakan yang regulatif (aktif).

Di era Reformasi yang singkat (Mei 1998-Oktober 1999) terdapat dua Keputusan Menteri Tenaga Kerja yakni No. 204 Tahun 1999 Tentang Penempatan Tenga Kerja Indonesia di Luar Negeri dan Keputusan Menteri yaitu No.92 Tahun 1998 tentang skema asuransi sosial yang dibangun untuk buruh migran. Sayangnya, dua Kepmenaker tersebut tidak banyak 
mengatur soal perlindungan bagi buruh migran melainkan lebih mengatur soal aspek manajerial dan operasional.

Dimasa

pemerintahan

Abdurrahman Wahid (Oktober 1999- Juli 2001) Gusdur mempertegas komitmen Departemen Luar Negeri (Deplu) untuk memberi perlindungan dengan dikeluarkanya Keppres No. 109 Tahun 2001 jo Kepmenenlu No.053 Tahun 2001. Melalui Keppres ini dibentuklah Direktorat baru di Deplu yaitu Direktorat Perlindungan WNI dan Badan Hukum Indonesia (BHI). Pada masa pemerintahan Gusdur pula dibentuk Serikat Buruh Seluruh Indonesia (SBI) yang getol melakukan pembelaan terhadap aktivitas buruh. Sementara langkah lain yang dilakukan adalah mencabut UndangUndang No. 25 Tahun 1997 Tentang ketenagakerjaan yang eskploitatif, anti serikat dan tidak ada proteksi terhadap TKI, serta membuat Peraturan Menteri Tenaga Kerja No 150 Tahun 2000 Tentang pesangon sebagai antisipasi dampak pemberhentian kerja.

Dimasa pemerintahan Megawati, lahir UU nomor 39 Tahun 2004 Tentang Penempatan dan Perlindungan Tenga Kerja Indonesa di Luar Negeri (PPTKILN). Sayangnya regulasi ini juga lebih menitik beratkan pada aspek tata niaga minus
perlindungan.Pemerintahan Megawati juga membentuk Badan Nasional Penempatan dan perlindungan Tenaga Kerja Indonesia (BNP2TKI).

Pada masa pemerintahan SBY banyak juga regulasi yang dikeluarkan termasuk PP Nomor 3/2013 tentang Perlindungan Tenaga Kerja Indonesia di Luar Negeri, dan banyak kebijakan lainnya.Begitu halnya dengan masa pemerintahan Presiden Jokowi yang menempatkan isu perlindungan pekerja migran menjadi salah satu persoalan serius dan menjadi prioritas.Namun kebijakan Kemenakertrans yang mengeluarkan moratorium pengehentian pengiriaman pekerja migran ke luar negeri menuai pro kontra karena bertentangan dengan salah satu hak dasar berdasarkan Konvensi 1990 yakni hak untuk bekerja ke luar negeri.

\section{METODE PENELITIAN}

Pendekatan yang digunakan adalah pendekatan kualitatif dengan Observasi, Indepth Interview dan Desk review sebagai tehnik pengumpulan data.

ANALISIS DAN PEMBAHASAN

Kebijakan Pemerintah Daerah Terkait

\section{Buruh Migran}


Pada awalnya, persoalan migrasi tenaga kerja Indonesia asal Lombok Timur ke Luar Negeri hampir dapat dikatakan sebagai 'aib' dan tabu untuk dibicarakan karena aktifitas ini dianggap sebagai beban politis bagi pemerintah (Haris, 2004). Fenomena migrasi penduduk menjadi salah satu indikator kegagalan pemerintah dalam pembangunan kaitannya dengan penyediaan lapangan kerja di daerah asal. Namun, pemerintah lokal mulai mengambil langkah kebijakan rasional seiring dengan perkembangan dan keterbukaan daerah. Migrasi internasional mulai dilihat sebagai salah satu aspek penting proses pembangunan daerah sehingga diintegrasikan ke dalam berbagai bentuk kebijakan atau program meskipun tetap saja lebih bermuatan politis dibandingkan berorientasi pemberdayaan masyarakat. Berikut ini beberapa dokumen kebijakan pemerintah daerah kabupaten Lombok Timur sebagai wujud dari komitmen atau political will pemerintah daerah terhadap perlindungan buruh migrant. Setidaknya ada tiga dokumen yang mencerminkan komitmen pemerintah daerah terkait dengan perlindungan buruh migrant yaitu ; 1). Peraturan daerah kabupaten Lombok Timur No. 12 tahun 2006 tentang Penempatan, Perlindungan dan
Pembinaan Tenaga Kerja Indonesia Asal Kabupaten Lombok Timur. 2). Rencana Pembangunan Jangka Menengah Daerah (RPJMD) kabupaten Lombok Timur tahun 2013- 2018 ; dan 3). Rencana Strategis Dinas Sosial Transmigrasi dan Tenaga Kerja kabupaten Lombok Timur tahun 2013- 2018

Perda No. 12 Tahun 2006 tentang Penempatan, Perlindungan dan Pembinaan Tenaga Kerja Indonesia Asal Kabupaten Lombok Timur.

Peraturan daerah (Perda) No. 12 ini terdiri dari 11 bab dan 49 pasal. Dasar pertimbangan ditetapkan peraturan daerah ini adalah : a) untuk menjamin tersedianya lapangan kerja dan memastikan agar setiap orang mempunyai hak dan kesempatan yang sama untuk bekerja sebagai salah satu upaya meningkatkan kesejahteraan hidupnya; b) untuk memberikan perlindungan hukum bagi tenaga kerja berdasarkan prinsip-prinsip demokrasi, keadilan, kesetaraan gender, anti diskriminasi, dan anti perdagangan manusia; c) memberikan perlindungan, dan pembinaan kepada Tenaga Kerja Indonesia asal Kabupaten Lombok Timur sebagai implementasi dari perlindungan dan pelayanan serta pembinaan; d) menjamin partisipasi semua pihak, 
khususnya pemerintah Kabupaten Lombok Timur dalam memberikan perlindungan kepada warganya baik didalam maupun di luar negeri seiring dengan makin meningkatnya kasus-kasus yang merugikan Tenaga Kerja Indonesia asal Kabupaten Lombok Timur baik material maupun immaterial.

Tujuan perlindungan dan pembinaan Tenaga Kerja atau buruh migrant asal Kabupaten Lombok Timur sebagaimana diatur dalam bab II pasal 3 adalah : a) Menjamin hak-hak ekonomi, politik, budaya, hak keselamatan kerja dan syarat kondisi kerja, serta hak kesehatan dan hak reproduksi bagi perempuan; b) Memberdayakan dan mendayagunakan Tenaga Kerja Indonesia asal Kabupaten Lombok Timur secara optimal dan manusiawi; c) Menjamin dan melindungi Calon TKI/TKI asal Kabupaten Lombok Timur sejak pra penempatan, penempatan sampai purna penempatan; d) Mewujudkan pemerataan dan kesempatan kerja dan penyediaan tenaga kerja yang sesuai dengan kebijakan pembangunan daerah.

Tugas, kewajiban dan tanggung jawab pemerintah daerah sebagaimana diatur dalam bab III pasal 5 adalah : Pemerintah daerah bertanggung jawab untuk meningkatkan upaya perlindungan
TKI diluar negeri. Dalam melaksanakan tugas dan tanggung jawab dimaksud Pemerintah daerah berkewajiban : 1). Menjamin terpenuhinya hak-hak calon TKI/TKI, baik yangberangkat melalui Pelaksana penempatan TKI maupunyang berangkat secara mandiri; 2). Mengawasi pelaksanaan penempatan calon TKI; 3). Membentuk dan mengembangkan sistem informasipenempatan calon TKI diluar negeri; 4). Memberikan perlindungan kepada TKI selama sebelum pemberangkatan, masa penempatan dan masa purnapenempatan.

Sementara yang terkait dengan hak dan kewajiban TKI atau buruh migrant diatur pada bab IV pasal 7 dimana dalam pasal tersebut dijelaskan bahwa semua TKI/ Buruh Migran mempunyai hak yang sama untuk : 1).Bekerja diluar negeri; 2).Memperoleh informasi yang benar mengenai pasar kerjaluar negeri dan prosedur penempatan TKI diluar negeri; 3).Memperoleh pelayanan dan perlakuan yang sama dalampenempatan diluar negeri; 4).Memperoleh kebebasan menganut agama dan keyakinannya serta kesempatan untuk menjalankanibadah sesuai dengan agama dan keyakinan yangdianutnya; 5).Memperoleh upah sesuai dengan standar upah yangberlaku di negara tujuan; 6).Memperoleh hak, 
kesempatan dan perlakuan yang samayang diperoleh tenaga kerja asing lainnya sesuai denganperaturan perundang-undangan di negara tujuan; 7).Memperoleh jaminan perlindungan hukum sesuai denganperaturan perundang-undangan atas tindakan yang dapatmerendahkan harkat dan martabatnya serta pelanggaranatas hakhak yang ditetapkan sesuai dengan peraturanperundang-undangan selama penempatan diluar negeri; 8).Memperoleh jaminan perlindungan keselamatan dankeamanan kepulangan TKI ketempat asal; dan 9).Memperoleh naskah perjanjian kerja yang asli.

Adapun tata cara penempatan atau prosedur rekruitmen buruh migrant diatur dalam bab $\mathrm{V}$ pasal 9 sampai dengan pasal 93 yang intinya adalah mengatur tata cara penempatan TKI atau buruh migrant mulai dari pra penempatan/ pemberangkatan, masa penempatan hingga purna penempatan atau setelah buruh migrant kembali ke daerah asal . Pra penempatan mulai dari pelayanan informasi di atur dalam pasal 9 , pendataan TKI (ps 10), Perekrutan dan seleksi calon TKI (ps 11- 15), pendidikan dan pelatihan (ps. 16-19), pemerikasaan kesehatan (ps. 20). Masa Penempatan TKI di atur dalam pasal 21- 38 mengenai syarat- syarat penempatan dan Purna penempatan di atur mulai dari pasal 3943 yang intinya adalah bagaimana memberikan kemudahan dan keamanan serta kenyamanan bagi setiap TKI atau buruh migran yang hendak kembali ke tanah air atau daerah asal.

\section{Rencana Pembangunan Jangka Menengah (RPJMD) 2013-2018}

Rumusan visi pembangunan Kabupaten Lombok Timur periode 20132018 adalah "Mewujudkan Lombok Timur yang Aman, Adil dan Sejahtera Lahir dan Batin dalam Bingkai Persatuan dan Kesatuan Dilandasi Iman dan Taqwa". Untuk dapat mewujudkan visi pembangunan daerah tersebut Pemerintah Kabupaten Lomnbok Timur telah menetapkan 8 misi pembangunan daerah. Di antara misi-misi tersebut, persoalan ketenagakerjaan termasuk dalam misi keduayakni : Meningkatkan kualitas dan produktivitas Sumber Daya Manusia. Pemerintah Kabupaten telah menetapkan 17 tujuan untuk mencapai visi-misi dimaksud dan salah satu diantaranya adalah tujuan No. 3 yaitu meningkatkan kualitas ketenagakerjaan formal dan informaldengan 2 sasaran masing-masing : 1). Terwujudnya ketrampilan tenaga kerja sektor formal dan informal; dan 2). Tersedianya 
instrumen perlindungan tenaga kerja.dan keluarganya.

Berdasarkan isu strategis dan kewenangan pemerintah daerah (urusan wajib dan urusan pilihan), agenda prioritas pembangunan di bidang ketenagakerjaan adalah program terkait peningkatan kualitas tenaga kerja meliputi : Peningkatan kualitas dan produktifitas tenaga kerja; Peningkatan kesempatan kerja; Perlindungan dan pengembangan lembaga ketenagakerjaan.

Rencana Strategis Dinas Sosial Tenaga Kerja dan Transmigrasi Kabupaten Lombok Timur Tahun 2013-2018

Visi Dinas Sosial Tenaga Kerja dan Transmigrasi sebagaimana tercantum dalam Renstra 2013-2018 adalah "Terwujudnya Peningkatan Kesejahteraan Sosial, Produktifitas dan Perlindungan Tenaga Kerja serta Mobilitas Penduduk yang Aman dan Tertib". Dari 5 (lima) rumusan misi, masalah ketenagakerjaan diakomodir dalam 2 (dua) misi masingmasing : Misi 4. Mengembangkan dan memperluas kesempatan kerja melalui pelatihan dan pengembangan produktifitas; dan Misi 5. Peningkatan perlindungan tenaga kerja, pengembangan hubungan industrial dan pelayanan masyarakat ketenagakerjaan yang profesionalisme. Dalam kurun waktu
2013-2018, Dinas STT telah menetapkan 11 tujuan jangka menengah di antaranya : meningkatnya keterampilan pencari kerja dan calon transmigran; meningkatnya jumlah angka penempatan tenaga kerja dan menurunnya angka pengangguran; tersedianya fasilitas pelayanan ketenagakerjaan yang memadai.

Keberadaan Perda No. 12 Tahun 2006 tentang Penempatan, Perlindungan dan Pembinaan Tenaga Kerja Indonesia Asal Kabupaten Lombok Timur, dan dokumen lain seperti RPJMD kabupaten Lombok Timur dan RENTRA Dinas Sosial Transmigrasi dan Tenaga Kerja menunjukkan kuatnya kemauan politik (political will) Pemerintah Daerah untuk mengatur proses penempatan dan perlindungan serta pembinaan buruh migran. Namun demikian, regulasi yang tertuang dalam dokumen- dokumen tersebut masih terlalu normative dan diakui kurang operasional. Demikian pula pada tataran implementasi Perda ini belum berjalan seperti yang diharapkan.

Rendahnya kapasitas fiskal daerah menjadi kendala utama bagi Pemerintah Lombok Timur dalam mengalokasikan anggaran untuk mengiplementasikan Perda maupun aturan- aturan lain yang terkait dengan perlindungan buruh 
migran secara memadai baik sebelum pemberangkatan, saat TKI bekerja di Negara tujuan dan program pemberdayaan setelah kembali ke desa asal (Lombok). Sebelum pemberangkatan, Pemerintah Kabupaten berposisi sebagai penerima 'daftar TKI' saja beserta dokumennya karena proses rekruitmen dilakukan oleh Pihak Perusahaan Jasa Tenaga Kerja Indonesia. Jika dari 'daftar' tersebut diketemukan adanya tenaga kerja tidak sesuai prosedur atau tidak memenuhi persyaratan maka Pemerintah akan melarang calon TKI berangkat. Misalnya, Dinas STT akan melarang calon TKI di bawah umur 18 tahun karena tidak sesuai dengan ketentuan batas minimal umur pekerja.

Dinas STT biasanya melakukan sosialisasi hingga ke tingkat desa guna meminimalisir keberadaan calon TKI yang tidak memenuhi ketentuan dan aturan sehingga tidak menimbulkan persoalan di kemudian hari. Sayangnya, upaya penyadaran masyarakat ini belum mampu menjangkau semua desa yang ada di seluruh wilayah Lombok Timur karena minimnya anggaran yang dikelola Bidang Bina Hubungan Industrial dan Perlindungan TK.

Minimnya anggaran untuk perlindungan Tenaga Kerja Indonesia asal
Lombok Timur diakui juga oleh salah seorang Anggota DPRD Lombok Timur meskipun kontribusi para buruh migran sangat signifikan bagi pembangunan daerah jika dilihat dari besarnya remitansi yang mencapai lebih dari 1 Triliun. Kebijakan anggaran pembangunan daerah masih diarahkan pada penyelesaian sejumlah proyek-proyek bangunan fisik guna meningkatkan kualitas pelayanan publik. Ikhtiar menaikkan anggaran untuk perlindungan TKI asal Lombok Timur telah dilakukan oleh pemerintah bersama legislative (DPRD), namun Pemerintah Daerah tampaknya beberapa tahun terakhir ini masih fokus untuk merampungkan beberapa proyek fisik.

\section{KESIMPULAN DAN SARAN}

\section{Kesimpulan}

Beberapa kesimpulanyang dapat di tarik dari hasil kajian ini berdasarkan uraian dalam latar belakang maupun pembahasan dari analisa data sekunder, review kebijakan dan wawancara mendalam adalah sebagai berikut:

1. Keberadaan Perda No. 12 Tahun 2006 tentang Penempatan, Perlindungan dan Pembinaan Tenaga Kerja Indonesia Asal Kabupaten Lombok Timur menunjukkan kuatnya kemauan politik (political will) Pemerintah 
|64 Jalaludin, Irwan Suriadi/Analisis KebijakanPengelolaan...

daerah untuk memberikan perlindungan dan pembinaan buruh migran. Namun karena minimnya anggaran, perda ini menmjadi kurang implementiti.f

2. Dokumen kebijakan daerah (RPJMD dan RENSTRA) masih terlalu normatif dan hanya menyasar aspek ketenagakerjaan secara umum sehingga kebijakan pada isu buruh migran belum terlihat secara jelas.

3. Kebijakan daerah terkait perlindungan dan mekanisme penempatan Tenaga Kerja Indonesia (TKI) masih lemah. Proses perekrutan dan penempatan TKI masih relative panjang, biaya pengurusan dokumen masihdirasakan cukup mahal.

4. Rendahnya kapasitas fiskal daerah menjadi kendala utama bagi Pemerintah Lombok Timur dalam mengalokasikan anggaran untuk perlindungan buruh migran secara memadai baik sebelum pemberangkatan, saat TKI bekerja di Negara tujuan dan program pemberdayaan setelah kembali ke daerah asal.

\section{Saran}

1. Agar Perda No. 12 tahun 2006 lebih implementatif, maka perlu didukung oleh regulasi yang lebih operasional dalam bentuk Peraturan bupati atau Keputusan bupati. Hal ini penting mengingat peraturan bupati atau keputusan bupati lebih operasional karena tidak selalu harus meminta persetujuan legislative untuk mengeksekusinya sehingga persoalan minimnya anggaran tidak lagi menjadi kendala dalam penangan persoalan buruh migran.

2. Ditemukannya sejumlah kasus perdagangan manusia dalam alur pengiriman buruh migran ke Luar Negeri, menunjukkan masih longgarnya pengawasan pemerintah maupun aparat terkait. Pemerintah diharapkan melakukan pengawasan dan bertindak tegas terhadap segala bentuk penyelewengan dan penyalah gunaan wewenang yang terkait dengan pengiriman buruh migrant. Hal ini bisa dimulai dari desa dengan membangun system administrasi dan tata kelola pemerintahan desa yang baik. Demikian juga SDM perangkat desa dan peran komonitas masyarakat sebagai lembaga control perlu diberdayakan. 


\section{DAFTAR PUSTAKA}

Agustino, L dan M.A. Yusoff. 2010. Politik Lokal di Indonesia : Dari Otokratik ke Reformasi Politik. Jurnal Ilmu Politik, Edisi 21, 2010.

Anderson, J.E. 2011. Public Policy Making : An Introduction, Seventh Edition. Wadsworth USA.

Braun, J. V., \& Grote, U. (2002), Does Decentralization Serve the Poor ?", in Ethisham A., \& Tanzi, V. (eds), Managing Fiscal Decentralization, London: Routledge.

Badan Pusat Statistik NTB, Data Sensus Penduduk 2010 dan berbagai tahun

Damsar, Pengantar Sosiologi Politik, Jakarta: Kencana, 2012.

Balawala Mansetus, 2016 : Menggagas Kebijakan Migrasi bebasis Konvensi 1990, laylylay.blogspot.co.id/2016/04

Darmawan, D. R. E., 2008. The practice of decentralization in Indonesia and its implications on local competitiveness. Public Administration-Public Governance Study, School of Management and Government, University of Twente, Enschede, The Neterlands

Darwin Muhajjir, 2015, Proses kebijakan dan Analisis kebijakan publik, Workshop Pembangunan berwawasan kependudukan bagi kepala bidang Pengendalian penduduk dan ketua pusat studi kependudukan seluruh Indonesia, PSKK UGM

Dye, T.R. 1978. Understanding Public Policy. Prentise Hall, Amerika.

Etzioni, Amitai, What is Political? (2003). CSA Worldwide Political Science Abstracts, 2006. Available at SSRN: http://ssrn.com/abstract $=2157170$

Hedi Sasrawan, 2013, Artikel Pengertian Politik (http://hedisasrawan.blogspot.co.id/2013/12), diakses tgl 4 Juni 2016

Harriss, J., K. Stokke and O. Törnquist. 2005. Introduction: The New Local Politics of Democratisation. In Harriss, J et al (Ed). Politicising Democracy : The New Local Politics of Democratisation. Palgrave Macmillan.

Jalaludin dan Moh. Taqiuddin, 2015 ;Studi Dampak Kependudukan terhadap Perubahan Sosial Ekonomi : Kasus Buruh Migran di Kabupaten Lombok Timur. BKKBN Perwakilan NTB

Kritz, M.M and H. Zlotnik. 1992. "Global Interaction, Migration Systems, Process and Policies", in Mary M. Kritz, et.al. (eds)., International Migration System: A Global Approach. Oxford: Clerandon Press. 
|66Jalaludin, Irwan Suriadi/Analisis KebijakanPengelolaan...

Midgley, J and M. Livermore. 2008. The Handbook of Social Policy. SAGE Publishing.

Potter, J. 1998. Best Practices in Local Development. The Local Economic and Employment Development Programme. OECD.

Ribot, J. C., 2007. Representation, citizenship and the public domain in democratic decentralization. Development.

Ruman, Y.S. 2011. Desentralisasi, Basis Sosial Dan Praktek Kekuasaan Elit Politik Di Tingkat Lokal Pasca Penerapan Otonomi Daerah. HUMANIORA Vol.2 No.1 April 2011: 2432.

Sudirman, 2012. Dinamika Politik Lokal dalam Social Capital. JURNAL ACADEMICA FISIP Untad VOL.04 No. 01 PEBRUARI 2012.

Titus, M.J. 1978. Interegional Migration in Indonesia as A Reflection of Social and Regional Inequalities. Yogyakarta: Population Studies Center.

Utina, World Bank, 2006. Trends, Determinants, and Macroeconomic Effects of Remittances, World Bank. 